\title{
Correlates of Psychosexual Issues in the Jamaican Population
}

\author{
G Walcott ${ }^{1}$, FW Hickling ${ }^{2}$
}

\begin{abstract}
Objective: To examine the relationship between the psychopathological correlates of psychosexual phenomena in post-colonial Jamaica.

Methods: A total of 1506 adult individuals were sampled from 2150 households using a stratified sampling method and assessed with the Jamaica Personality Disorder Inventory (JPDI). Responses to the seven questions on the psychological features of homosexual practices, sexual practices and dysfunction were tabulated and analysed using the Statistical Package for the Social Sciences (SPSS) version 17.

Results: Of the sample, $79.38 \%$ denied having phenomenological symptoms of psychosexual phenomena while $20.33 \%$ of the population admitted to having some degree of heterosexual and homosexual phenomena, ranging from mild (5.13\%), to moderate (11.40), or severe $(3.80 \%)$. Sixteen $(1.06 \%)$ responders described homosexual practices in their lives, and $53(3.52 \%)$ described thinking frequently about homosexual experiences in their subjective psychic lives. Significantly more $(\mathrm{p}>0.001)$ male responders $(348,23.11 \%)$ had difficulty being sexually faithful to one person at a time than females $(122,8.10 \%)$. The lower class cohort members $(348,23.11 \%)$ were more likely to have had multiple sexual relationships over the previous 12 months than socio-economic class (SEC) 1-3 responders (54, $3.58 \%)$ and were more likely $(681,45.21 \%)$ to fantasize about sexual relationships with persons other than their partners $(\mathrm{p}<0.001)$ than SEC 1-3 responders (94, 6.24\%).

Conclusion: Significant levels of multiple sexual partnerships and feelings of infidelity in a swathe of Jamaican people reveal underlying psychosexual anxiety and guilt, poor impulse control and difficulties with partner intimacy. This psychopathology is correlated to concomitant high-risk public health sexual behaviour such as teenage pregnancy, sexually transmitted diseases (STDs) and HIV/AIDS existing in the Jamaican society.
\end{abstract}

Keywords: Conflict, Jamaican population, Jamaica Personality Disorder Inventory (JPDI), psychosexual dysfunction

\section{Correlatos de Problemas Psicosexuales en la Población Jamaicana}

\author{
G Walcott ${ }^{1}$, FW Hickling ${ }^{2}$
}

\begin{abstract}
RESUMEN
Objetivo: Examinar la relación entre los correlatos psicopatológicos de los fenómenos psicosexuales en la Jamaica postcolonial.

Métodos: Un total de 1506 individuos adultos fueron tomados como muestras a partir de 2150 hogares, usando un método de muestreo estratificado, y evaluados mediante el Inventario de Trastornos de la Personalidad de Jamaica (JPDI). Las respuestas a las siete preguntas sobre las características psicológicas de las prácticas homosexuales, las prácticas sexuales, y la disfunción, fueron tabuladas y analizadas mediante el Paquete Estadístico para las Ciencias Sociales (SPSS) versión 17.

Resultados: De la muestra, 79.38\% negó tener sintomas fenomenológicos de fenómenos psicosexuales, mientras que el $20.33 \%$ de la población admitió haber tenido algún grado de fenómenos heterosexuales $y$ homosexuales, desde leves (5.13\%) a moderados (11.40) o severos (3.80\%). Once encuestados $(0.73 \%)$ reportaron prácticas homosexuales en sus vidas, y 53 (3.52\%) reportaron pensar con frecuencia acerca de experiencias homosexuales en su vida psíquica subjetiva. Significativamente más
\end{abstract}

From: ${ }^{1}$ South East Regional Health Authority, Kingston and St Andrew Public Health Service, 1 Marescaux Road, Kingston 5, Jamaica and ${ }^{2}$ Caribbean Institute of Mental Health and Substance Abuse, The University of the West Indies, Kingston 7, Jamaica.
Correspondence: Dr G Walcott, South East Regional Health Authority, Kingston and St Andrew Public Health Service, 1 Marescaux Road, Kingston 5, Jamaica. E-mail: dr.gwalcott@gmail.com 
encuestados varones ( $\mathrm{p}>0.001)(348,23.11 \%)$ tuvieron dificultades para ser fieles sexualmente a una persona alguna vez, en comparación con las hembras (122, 8.10\%). Los miembros de la cohorte de clase baja $(348,23.11 \%)$ eran más propensos a tener múltiples relaciones sexuales en los 12 meses anteriores (3.58\%), y tuvieron una mayor probabilidad (681, 45.21\%) de tener fantasías acerca de relaciones sexuales con personas que no eran sus parejas $(\mathrm{p}<0.001)$ en comparación con los encuestados de SEC 1-3 (94, 6.24\%).

Conclusión: Los niveles significativos de las relaciones sexuales múltiples y los sentimientos de la infidelidad en un sector del pueblo jamaicano, revelan ansiedad psicosexual subyacente y sentimientos de culpa, control de impulsos pobre, y dificultades con la intimidad de la pareja. Esta psicopatología está correlacionada con comportamientos sexuales concomitantes de alto riesgo en la salud pública, tales como el embarazo adolescente, las enfermedades de transmisión sexual (ETS), y el VIH/SIDA, existentes en la sociedad jamaicana.

Palabras claves: Conflicto, disfunción psicosexual, población Jamaicana, Inventario de Trastornos de Personalidad en Jamaica (JPDI)

West Indian Med J 2013; 62 (5): 418

\section{INTRODUCTION}

There is a strong global relationship between sexual risk behaviour (SRB) and unwanted public health consequences. An estimated 32000 persons are currently living with HIV/ AIDS in Jamaica, an adult prevalence of $1.7 \%$ in 2011 , of which half are unaware of their HIV status (1). In 2013, Jamaica was ranked $33^{\text {rd }}$ in adult HIV/AIDS prevalence rate among countries in the world (2) and joins the Caribbean region as having the second highest rate of HIV/AIDS behind sub-Saharan Africa (3). The primary contributors to the epidemic are sociocultural, behavioural, and economic factors that result in risky behaviours such as multiple sex partners, older men having sex with younger women, and early sexual debut. The 2012 Knowledge, Attitudes, Practices and Behaviour (KAPB) study that surveyed 1800 adults between the ages of 15 and 49 years in Jamaica indicates that $51 \%$ of the sexually active respondents reported having multiple partnerships in the past 12 months, an increase of $2.1 \%$ since the previous KAPB in 2008. More specifically, the incidence of multiple partnerships was significantly higher in the 15 24-year age group with $52.4 \%$ of the respondents reporting having multiple sex partners (4). A third of Jamaicans reported sexual practices that increase their risk of HIV infection and other sexually transmitted diseases [STDs] (5). Adolescent pregnancy continues to be a major public health challenge in Jamaica. Approximately $18 \%$ of children born in Jamaica are attributed to adolescent girls. They are also more likely to have premature babies, complications during labour, babies with low birthweight and low use of antenatal healthcare. There is an increasing number of pregnant teenage girls who are also contracting HIV/AIDS (6). Highrisk sexual practices in teenagers have attracted increasing newspaper and authority concern in Jamaica as a reflection of morally and socially unacceptable practices (7). The report chronicled accounts of students of a Kingston high school being caught by a security guard engaging in oral sex in a fast food restaurant in downtown Kingston. The 'no panty day' on the public buses is now a common practise by Jamaican schoolgirls as part of the sexual revolution to provide easier access to the genitals for petting and lap sex (8). These are some of the dysfunctional sexual practices in contemporary Jamaica that culminate in moral and public health sequelae.

Recent studies of personality disorder in Jamaica have highlighted psychosexual phenomenology secondary to emotional and/or mental causes as a significant component of the 'clinical triad' of that condition, with issues ranging from sexual dysfunctions to sexual performance difficulties resulting in dysfunctional behaviour (9). The objective of this study is to cull the prevalence of psychosexual phenomena in the Jamaican society in order to examine the relationship between the psychopathological correlates of psychosexual issues in Jamaica and dysfunctional sexual expression in this post-colonial country.

\section{SUBJECTS AND METHODS}

A total of 1506 adult individuals were sampled from 2150 households using a stratified sampling method to reflect the demographics of the general population. The survey was conducted by Market Research Services Limited (10), a Jamaican market research firm with almost 30 years of experience in conducting market research programmes in Jamaica and across the Caribbean. A four-stage stratified random sampling method was used to identify the target population. The population was assessed using the Jamaica Personality Disorder Inventory (JPDI). The methodology is described elsewhere (11).

\section{Diagnostic measures}

Jamaica Personality Disorder Inventory (JPDI): This is a 38-item interviewer administered questionnaire that was developed by The University of the West Indies (UWI), Section of Psychiatry, as a screening tool to identify the 
probability of being diagnosed with a personality disorder. Taking approximately 30 minutes for administration, the JPDI is intended to be linguistically simple and relevant to the reconceptualization of personality disorder. The JPDI has demonstrated reliability, and criterion-related and discriminant validity (11). The JPDI has questions that were carefully designed by a focus group of psychiatrists and psychologists from The UWI to 'capture' the three phenomena of the 'clinical triad' of personality disorder (9). A psychological phenomenon is a subjective and/or objective experience of human psychic life. The clinical triad is divided into three categories: physiological and psychological dependency (questions 1 to 17), power management (questions 18 to 29) and psychosexual issues (questions 30-37). The JPDI's questions on the phenomenology of sexual issues are grouped into three sub-groups that attempt to cull critical aspects of psychosexual areas of homosexual practices (questions 30-31), generalized sexual practices (questions 32-34) and sexual dysfunction (questions 35-37). The seven questions investigating the psychosexual phenomenon are displayed in Table 1.

\section{Statistical analysis}

The database of responses to the demographic and JPDI questionnaires was created and analysed using the Statistical Package for the Social Sciences (SPSS) version 17. Chisquared analysis was used to assess the differences in the responses for the population seen within a range of sociodemographic characteristics.

\section{RESULTS}

The total population sample for this study was 1506 persons with 727 males and 779 females. There were 574 persons in lasting meaningful relationships and 932 persons not in lasting meaningful relationships. The persons were recruited from the fourteen parishes of Jamaica with 694 persons recruited from urban centres and 812 from rural areas. The persons were divided into three groups for socio-economic class (SEC), using the UK Registrar General's Classification by Occupation (12): SEC 1-3 (upper, middle and lower middle class), SEC 4 (skilled working class) and SEC 5 (working class and lowest level of subsistence). There were 155 persons in SEC 1-3, 387 in SEC 4 and the majority in SEC 5 (Table 2).

Table 2: Demographics

\begin{tabular}{|c|c|c|}
\hline Demographic & & Number (\%) \\
\hline \multirow[t]{2}{*}{ Gender } & Male & $727(48.3)$ \\
\hline & Female & 779 (51.7) \\
\hline \multirow[t]{4}{*}{ Relationship status } & In relationship & $574(38.1)$ \\
\hline & Not in relationship & 932 (61.9) \\
\hline & $18-24$ & $281(18.7)$ \\
\hline & $25-34$ & $399(26.5)$ \\
\hline \multirow{3}{*}{ Age (years) } & $35-44$ & $388(25.8)$ \\
\hline & $45-54$ & $263(17.5)$ \\
\hline & $55-64$ & $175(11.6)$ \\
\hline \multirow[t]{3}{*}{ Socio-economic status } & SEC 1-3 & $155(10.3)$ \\
\hline & SEC 4 & $387(25.7)$ \\
\hline & SEC 5 & $964(64)$ \\
\hline \multirow[t]{2}{*}{ Location } & Rural & $812(53.9)$ \\
\hline & Urban & $694(46.1)$ \\
\hline
\end{tabular}

Cumulative responses (scores) to psychosexual phenomena questions

With each question scoring yes (positive response, scoring 1 ), or no (negative response, scoring 0 ), the cumulative maximum negative responses were scored for the entire population and the total cumulative positive responses were scored for the questionnaire. An analysis of these scores revealed that $20.33 \%$ of the population admitted to having some of the psychosexual phenomenology problems in the questions posed. As the questionnaire allowed for people to answer on a Lickert scale of $0-5$ for severity, it was possible to categorize the number of positive responders with total cumulative scores ranging from mild $(5.13 \%)$, to moderate $(11.40 \%)$, or severe $(3.80 \%)$ [Table 3].

Table 1: The Jamaica personality disorder inventory (JPDI) psychosexual questions and psychological correlates

\begin{tabular}{lll}
\hline No. & JPDI items on psychosexual phenomena & Category of sexual issues \\
\hline 30 & $\begin{array}{l}\text { Have you ever had a homosexual/lesbian relationship? } \\
31\end{array} \quad \begin{array}{l}\text { Do you think about it frequently? } \\
\text { Do you have difficulty being sexually faithful to one person } \\
\text { at a time? }\end{array}$ & $\begin{array}{l}\text { Homosexual practices } \\
\text { Homosexual practices }\end{array}$ \\
$33 \quad \begin{array}{l}\text { Have you ever fantasized about a sexual relationship with someone } \\
\text { other than your partner? }\end{array}$ & Promiscuous practices \\
$34 \quad \begin{array}{l}\text { Have you had more than one sexual partner in the past 12 months? } \\
35 / 36\end{array}$ & $\begin{array}{l}\text { Po you have premature ejaculation or difficulty attaining an } \\
\text { orgasm/ejaculation? }\end{array}$ & $\begin{array}{l}\text { Promiscuous practices } \\
\text { Do you have guilt, pain or unpleasant feelings because of sex? }\end{array}$ \\
\hline
\end{tabular}


Table 3: Collective score for severity

\begin{tabular}{lrrcc}
\hline & Total score & Mean score & $\begin{array}{c}\text { Collective total } \\
\text { score }\end{array}$ & $\begin{array}{c}\text { Collective } \\
\text { percentage }\end{array}$ \\
\hline Never & 8263 & 1180.43 & 10542 & 78.38 \\
Minimum & 541 & 77.29 & 10542 & 5.13 \\
Moderate & 1202 & 171.71 & 10542 & 11.40 \\
Severe & 401 & 57.29 & 10542 & 3.80 \\
& & & & \\
\hline
\end{tabular}

The analysis of the total responses revealed that there were $16(1.06 \%)$ responders who described homosexual practices in their lives, and $53(3.52 \%)$ who described thinking frequently about homosexual experiences in their subjective psychic lives. Of the cohort, 470 (31.21\%) of the population responded positively to questions of having difficulties in being sexually faithful to their partner, 775 (51.46\%) fantasized about a sexual relationship with someone other than their partner and $402(26.69 \%)$ had experienced more than one sexual partner in the previous year. Two hundred and eighteen (14.48\%) persons described difficulties attaining orgasm and $218(14.48 \%)$ persons reported unpleasant subjective experiences of guilt and pain because of sex (Table 4). fantasize about sexual relationships outside of those with their partners and reported greater difficulty remaining faithful to one partner at a time than the female responders. Male responders $(22.84 \%)$ were also more likely to have had multiple partners over the previous 12 months $(p<0.001)$ than the female responders $(3.85 \%)$. Significantly more $(p>$ $0.001)$ male responders $(34.59 \%)$ reported having fantasized about a sexual relationship with someone other than their partner; only $16.87 \%$ of females reported this. The lower class (SEC 4 and 5) cohort members (23.11\%) were more likely to have had multiple sexual relationships over the previous 12 months than upper class SEC 1-3 responders $(3.58 \%)$ and were more likely $(45.21 \%)$ to fantasize about sexual relationships with persons other than their partners $(p<0.001)$ than upper and middle class responders $(6.24 \%)$. There was no significant difference between socio-economic groups with regards to remaining faithful to one partner at a time $(p>0.05)$.

\section{Sexual dysfunction}

Male responders $(8.37 \%)$ were significantly more likely $(p<$ 0.002 ) to experience having premature orgasm than female responders $(6.11 \%)$. There was no statistically significant

Table 4: Positive responders by gender and socio-economic status for psychosexual problems

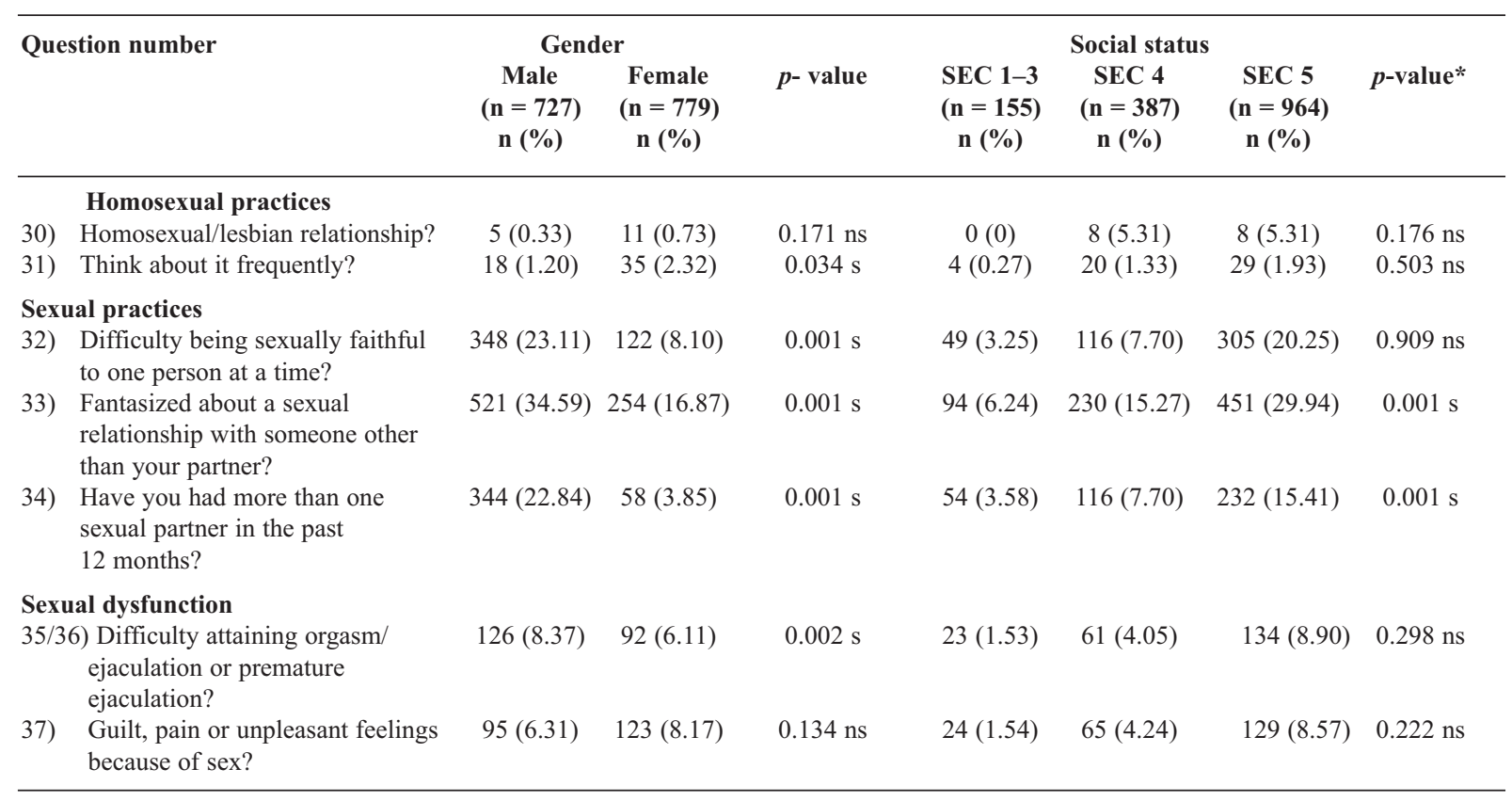

* SEC 4 and 5 combined for Chi-squared calculation

\section{Gender and socio-economic analysis of positive responders}

Sexual practices

The positive responders to the generalized questions on sexual faithfulness and dysfunction and homosexual practices were analysed for gender and socio-economic status. The results revealed that male responders were more likely to difference $(p>0.05)$ between the 95 male responders (6.31\%) and 123 female responders (8.17\%) who reported experiencing unpleasant feelings, guilt and pain because of sex nor was there statistically significant social class difference in the responders to the questions of sexual dysfunction $(p>0.05)$. 


\section{Homosexual practices}

There were no significant differences by gender or socioeconomic status for homosexual practices (male:female $=$ $5: 11, p>0.05$ ) but there were statistically significantly more women than men experiencing frequent homosexual thoughts $(\mathrm{M}: \mathrm{F}=18: 35, p>0.034)$. There was no statistically significant difference between the social classes of total responders for subjective or objective homosexual experiences in their psychic lives.

\section{DISCUSSION}

The seven questions about psychosexual phenomena in the JPDI were derived from focus group discussions between psychiatrists and clinical psychologists at The UWI Department of Psychiatry, and focussed around the clinical disturbances in sexual function that were considered to be egodystonic (ego alien) and resulted in dysfunctional behaviour with a partner or with the social/cultural environment. Understanding the responses to these questions from the JPDI must derive from the comprehension that the responses relate to subjective (internal) psychic experiences, or objective (external) actions or behaviours. Interpretation of the responses cannot be based on a value judgement spectrum of normal/ abnormal. Such a dimensional interpretation into a normal/ abnormal continuum converts these phenomena into personality traits. Livesley et al (14) remind us that personality traits are not directly observable but rather govern the pattern of behavioural responses and therefore are not pathological. These JPDI questions test phenomena rather than traits; thus it is possible/likely that these responses on thoughts of faithfulness to a partner can occur in many responders from the cohort, but are completely at variance with responses relating to the behaviour/activity of having multiple sexual partners in the previous year. The questionnaire responses reflect an exploration of the subjective and objective psychosexual phenomena of each responder, which in turn speaks to the ability of an individual to commit to an interpersonal and/or social contract based on socially agreed practices. All responders identified subjective and objective activities that they were engaged in that the responses to questions 35 to 37 about sexual dysfunction relate to admitted ego-dystonic symptoms of disharmonious feelings of unpleasantness (anxiety), guilt and emotional pain in their lives.

The data from this study described responses to phenomenological questions of disturbed sexual desire and performance of mental origin with the resulting inference of the responder's inability to fully enjoy sexual intercourse. In men, sexual dysfunctions may manifest as reduced sexual desire, premature or delayed ejaculation, impotence, or painful intercourse. The equivalent sexual dysfunctions would also apply to the female responders. The findings indicate that $20 \%$ of the responders demonstrated insight into sexual phenomena that caused them distress. The remaining $80 \%$ of the responding cohort either did not experience the ego-dystonic phenomena, or were insightless of their existence. Of the cohort, 31\% recognize their ego-dystonic sexual experiences, and $14 \%$ acknowledged difficulty in areas of sexual dysfunction. One per cent of the cohort admitted to having experienced homosexual relationships, although $4 \%$ admitted to having experienced frequent homosexual thoughts. In the original clinical cohort of Jamaican personality disordered patients, ego-dystonic homosexual behaviour often led to complex patterns of emotional dis-honesty and aggression (9).

The findings of this population cohort study suggest that male responders were more likely than the female responders to have high levels of fantasies of sexual activity with persons other than their partner $(p>0.001)$, and admitting to having multiple partners in the previous year $(p>$ 0.001). This translates to a cultural issue in the Jamaican society as captured in the lyrics of a popular song by dancehall artiste Beenie Man - 'gyal in a bungle' which suggests that a cohort of Jamaican men is unable/incapable of adhering to a monogamous social partnership contract, fulfilling an exclusive responsibility to their partner, and has been coined the "nuff gyal syndrome" (7). Eight per cent of male responders in this study also admitted to having premature orgasms, or having difficulty attaining an orgasm. This implies a high level of psychosexual anxiety, difficulty with impulse control and problems with intimacy in their psychosexual relationships. The findings from this study, combined with the worrying conclusion of more than $40 \%$ of the Jamaican population showing features of a mild, moderate or personality disorders (15), must be considered in conjunction with the identification of high sexually risky behaviour in Jamaicans, particularly adolescents and young adults (1-5) leading to profound public health challenges of teenage pregnancy, HIV/AIDS and dysfunctional sexual and social behaviour. Identifying personality disorder as a significant root cause of these public health challenges bring us closer to identifying appropriate evidence-based therapeutic practises to help to control this pathology at an individual and a social level.

\section{CONCLUSION}

Psychosexual dysfunction of pathological levels of mistrust and multiple partnerships in a significant swathe of Jamaican people reveals the psychopathology of psychosexual guilt and anxiety, poor impulse control and difficulties with partner intimacy. This psychopathology links underlying personality disorder problems with related findings from other Jamaican studies of high-risk sexual behaviour such as teenage pregnancy, STDs and HIV/AIDS that pose a significant public health challenge for the Jamaican society.

\section{REFERENCES}

1. Joint United Nations Programme on HIV/AIDS (UNAIDS). Global report: UNAIDS report on the global AIDS epidemic 2010; Geneva: UNAIDS; 2010.

2. UNAIDS. UNAIDS World AIDS Day Report 2011. How to get to zero: faster, smarter, better. Geneva: UNAIDS; 2011. 
3. CIA World Fact Book. Jamaica People 2013. Available from http://www.theodora.com/wfbcurrent/jamaica/jamaica_people.html

4. 2012 HIV/AIDS Knowledge Attitudes and Behaviour Survey, Jamaica Report of findings from HIV/AIDS Knowledge Attitudes and Behaviour Survey, Jamaica 2012. Kingston: Hope Caribbean Co Ltd; 2012.

5. Morgan ND, Ferguson TS, Younger NOM, Tulloch-Reid MK, Francis DK, McFarlane SR et al. Prevalence of high risk sexual behaviour in Jamaican adults and its relationship to socio-demographic and religious factors: findings from the Jamaica Health and Lifestyle Survey 20072008. West Indian Med J 2012; 61: 873-80.

6. National Family Planning Board. Jamaica Reproductive Health Survey 2008. Kingston: Derek Gordon Databank, The University of the West Indies; 2011.

7. Mills C. Risky sex practices by teens spark concerns. Jamaica Gleaner. 2004 April 4.

8. Little-White H. Up close and personal with panties. Jamaica Gleaner. 2008 March 9.
9. Hickling FW, Paisley V. Redefining personality disorder: a Jamaican perspective. Rev Panam Salud Publica 2011; 30: 255-61.

10. Market Research Services Limited (MRSL) [homepage on the Internet]. Kingston, Jamaica: Market Research Services Limited [cited 2011 Aug 31]. Available from: http://www.mrsl.com.jm/_

11. Hickling FW, Martin J, Walcott G, Paisley V, Hutchinson N, Clarke TR et al. The creation and validation of the Jamaica Personality Disorder Inventory. West Indian Med J 2013; 62: 389-96.

12. Rose D. Official social classifications in the UK [Internet]. Soc Res Update 1995 [cited 2009 Dec 9]; 9: 1-7. Available from: http:// sru.soc.surrey.ac.uk/SRU9.html

13. Thompson K. "Nuff gyal syndrome?" Psychiatrists say men with many women have a mental illness. The Jamaica Observer. 2011 April 17.

14. Livesley WJ, Schroeder ML, Jackson DN, Jang KL. Categorical distinctions in the study of personality disorders: implications for classification. J Abnorm Psychol 1994; 103: 6-17.

15. Hickling FW, Walcott G. Prevalence and correlates of personality disorder in the Jamaican population. West Indian Med J 2013; 62: 443 7. 